\title{
Assessment of apelin, apelin receptor, resistin, and adiponectin levels in the primary tumor and serum of patients with esophageal squamous cell carcinoma
}

\author{
Dorota Diakowska ${ }^{1, A-F}$, Krystyna Markocka-Mączka 2,A,B,E,F, Mirosław Nienartowicz 2,B,E,F \\ Joanna Rosińczuk ${ }^{1, C, E, F}$, Małgorzata Krzystek-Korpacka ${ }^{3, A, C-F}$ \\ ${ }^{1}$ Department of Nervous System Diseases, Faculty of Health Science, Wroclaw Medical University, Poland \\ ${ }^{2}$ Department of Gastrointestinal and General Surgery, Wroclaw Medical University, Poland \\ ${ }^{3}$ Department of Medical Biochemistry, Wroclaw Medical University, Poland \\ A - research concept and design; $\mathrm{B}$ - collection and/or assembly of data; $\mathrm{C}$ - data analysis and interpretation; \\ $\mathrm{D}$ - writing the article; $\mathrm{E}$ - critical revision of the article; $\mathrm{F}$ - final approval of the article
}

Address for correspondence

Dorota Diakowska

E-mail: dorota.diakowska@umed.wroc.pl

Funding sources

None declared

Conflict of interest

None declared

\section{Acknowledgements}

The authors would like to thank Dr. Elżbieta Klausa from the Regional Blood Donation and Treatment Center in Wrockaw (Poland) for supplying the serum of healthy individuals, and Dr. Anna Żołnowska's team from University Hospital №. 1, Wrockaw, for their assistance in the collection of blood and tissue samples.

Received on May 1, 2018

Reviewed on July 14, 2018

Accepted on August 9, 2018

Published online on January 7, 2019

Cite as

Diakowska D, Markocka-Mączka K, Nienartowicz M, Rosińczuk J, Krzystek-Korpacka M. Assessment of apelin, apelin receptor, resistin and adiponectin levels in the primary tumor and serum of patients with esophageal squamous cell carcinoma. Adv Clin Exp Med. 2018;28(5):671-678. doi: $10.17219 /$ acem/94135

DOI

10.17219/acem/94135

Copyright

Copyright by Author(s)

This is an article distributed under the terms of the Creative Commons Attribution Non-Commercial License (http://creativecommons.org/licenses/by-nc-nd/4.0/)

\begin{abstract}
Background. Disturbances in adipokine secretion are associated with the risk of cancer growth and progression.

Objectives. The aim of the study was to evaluate the mRNA expression and protein levels of apelin, the apelin receptor, resistin, and adiponectin in the tumor tissues of surgically treated esophageal squamous cell carcinoma (ESCC) patients. Concentrations of serum adipokines were assessed in relation to ESCC progression.

Material and methods. The study group consisted of 53 patients with ESCC and 27 controls. In the ESCC group, 27 patients were surgically treated and 26 were treated with palliative procedures. RT-PCR and ELISA tests were used to measure the mRNA expression and protein level of adipokines in tissues and their concentration in serum.

Results. We found that mRNA expression and protein concentrations of apelin, the apelin receptor and resistin were significantly higher in tumor tissue than in control tissue. The protein concentration of apelin were significantly increased in the tumors of patients with lymph node metastasis $(p<0.005)$. Circulating levels of apelin, the apelin receptor and resistin were significantly higher in the cancer patients than in controls $(p<0.05$ for all). The concentration of serum apelin receptor significantly decreased in patients with stage IV cancer, the presence of lymph node or distant metastasis $(p<0.05)$.
\end{abstract}

Conclusions. Apelin may participate in lymphangiogenesis and the progression of ESCC. The apelin receptor is intensely produced in the early stage of cancer development and it may take part in the carcinogenic processes of ESCC.

Key words: adipokines, apelin, esophageal squamous cell carcinoma, apelin receptor 
Adipokines are proteins secreted by the adipose tissue. They play an important role in energy homeostasis, lipid and glucose metabolism and insulin resistance ${ }^{1}$, and may act as autocrines, paracrines or endocrines. ${ }^{2,3}$ Several clinical studies have demonstrated a significant relationship between unbalanced adipokine secretion and the prevalence of endometrial, renal, colon, or gastrointestinal cancer. ${ }^{1,4-7}$ Adipocytes are important components of the tumor microenvironment and adipocytederived adipokines promote cancer growth, progression and angiogenesis. ${ }^{4,7}$

Esophageal squamous cell carcinoma (ESCC) is one of the most aggressive cancers, with rapid tumor growth and early metastasis to the lymph nodes. ${ }^{8}$ It has been suggested that abundant adipose tissue surrounding the esophagus at the adventitia influences the development of esophageal cancer. ${ }^{9}$ Recent studies have demonstrated the role of adipokines as new markers for predicting the stage of biological aggressiveness and prognosis of ESCC patients' survival., 7,8,10,11

Apelin and the apelin receptor are expressed not only in adipose tissue, but also in the human heart, liver, lung, gastrointestinal tract, and other organs. ${ }^{12}$ It has been reported that the apelin/apelin receptor system stimulates blood endothelial cell growth and may play a significant role in cancer angiogenesis and lymphangiogenesis. ${ }^{12,13}$ The possible involvement of apelin and the apelin receptor has not been evaluated in ESCC.

Resistin, like the apelin/apelin receptor system, promotes the growth, differentiation and migration of endothelial cells. It has been observed that elevated levels of serum resistin are associated with the progression of lung, colon, gastric, or oral cancer. ${ }^{2,8,14,15}$ In contrast, adiponectin inhibits endothelial cell proliferation and migration and stimulates cell apoptosis. ${ }^{7}$

In our previous study, we showed that a high resistin concentration in the serum of gastroesophageal cancer patients is associated with the cachexia syndrome and the presence of distant metastases, while low serum levels of adiponectin reflect adipose tissue wasting in these patients. ${ }^{10}$ Our results were in agreement with earlier immunohistochemical studies concerning high levels of resistin and apelin in tumors of gastroesophageal cancer patients. ${ }^{7,8,10,11}$ However, the importance of resistin and adiponectin has not been fully elucidated in ESCC.

There is no data concerning quantitative analyses of apelin, apelin receptor, resistin, and adiponectin concentrations in ESCC tumors. Therefore, in the present study, we evaluated the mRNA expression and protein levels of apelin, apelin receptor, resistin, and adiponectin in tumor tissues obtained from surgically treated ESCC patients. The association between protein levels of adipokines in tumors and disease progression was also investigated. Concentrations of serum apelin, apelin receptor, resistin, and adiponectin were measured in relation to ESCC progression.

\section{Material and methods}

\section{Patient characteristics}

The study population consisted of 80 individuals: 53 cancer patients with histopathologically confirmed squamous cell carcinoma of the esophagus and 27 healthy subjects. The ESCC patients (36 men and 17 women, mean age $58.8 \pm 8.8$ years) were admitted to the Department of Gastrointestinal and General Surgery of Wroclaw Medical University (Poland) between 2010 and 2015 for curative resection of esophageal tumors or for palliative procedures. Patients with any systemic illness were not included in the study. Preoperative evaluation included a physical examination and imaging techniques, such as ultrasonography, computed tomography and/or magnetic resonance. Finally, resection of the esophagus was carried out in 27 patients, and palliative methods (argon plasma coagulation supplemented with mechanical dilation of the tumor) were used in 26 patients. The patients' demographic, clinical and pathological data is given in Table 1.

The Union for International Cancer Control (UICC) TNM staging system ( $7^{\text {th }}$ edition) was used for clinical and pathological staging. There were 2 patients with stage I cancer,

Table 1. Characteristics of esophageal squamous cell carcinoma (ESCC) patients in whom studies of tissue samples $(n=27)$ and/or serum samples $(n=53)$ were performed. Descriptive data was expressed as median (min-max) or number (\%)

\begin{tabular}{|c|c|c|}
\hline Parameter & $\begin{array}{l}\text { Studies of tissue } \\
\text { samples } \\
\text { in } 27 \text { patients }\end{array}$ & $\begin{array}{l}\text { Studies of serum } \\
\text { samples } \\
\text { in } 53 \text { patients }\end{array}$ \\
\hline Age [years] & $59(42.0-74.0)$ & $59(39.0-88.0)$ \\
\hline $\begin{array}{l}\text { Age ranges [years] } \\
<60 \\
\geq 60\end{array}$ & $\begin{array}{l}14(51.9) \\
13(48.1)\end{array}$ & $\begin{array}{l}27(50.9) \\
26(49.1)\end{array}$ \\
\hline $\begin{array}{l}\text { Gender } \\
\text { male } \\
\text { female }\end{array}$ & $\begin{array}{l}17(63.0) \\
10(37.0)\end{array}$ & $\begin{array}{l}36(67.9) \\
17(32.1)\end{array}$ \\
\hline $\mathrm{BMI}\left[\mathrm{kg} / \mathrm{m}^{2}\right]$ & $20.4(17.3-24.5)$ & $20.5(16.4-24.5)$ \\
\hline $\begin{array}{l}\text { Cachexia } \\
\text { yes } \\
\text { no }\end{array}$ & $\begin{array}{c}7(25.9) \\
20(74.1)\end{array}$ & $\begin{array}{l}20(37.7) \\
33(62.3)\end{array}$ \\
\hline $\begin{array}{l}\text { Stage of disease } \\
\text { (TNM staging system) } \\
\text { । } \\
\text { II } \\
\text { III } \\
\text { IV }\end{array}$ & $\begin{array}{c}2(7.4) \\
9(33.3) \\
16(59.3) \\
0(0.0)\end{array}$ & $\begin{array}{c}2(3.8) \\
9(17.0) \\
16(30.2) \\
26(49.0)\end{array}$ \\
\hline $\begin{array}{l}\text { Primary tumor progression ( } \mathrm{T} \text { ) } \\
1 \\
2 \\
3 \\
4\end{array}$ & $\begin{array}{c}1(3.7) \\
8(29.6) \\
15(55.6) \\
3(11.1)\end{array}$ & $\begin{array}{c}1(1.9) \\
8(15.1) \\
15(28.3) \\
29(54.7)\end{array}$ \\
\hline $\begin{array}{l}\text { Lymph node metastasis (N) } \\
\text { N0 } \\
\text { N1 }\end{array}$ & $\begin{array}{l}14(51.9) \\
13(48.1)\end{array}$ & $\begin{array}{l}14(26.4) \\
39(73.6)\end{array}$ \\
\hline $\begin{array}{l}\text { Distant metastasis (M) } \\
\text { M0 } \\
\text { M1 }\end{array}$ & $\begin{array}{c}27(100.0) \\
0(0.0)\end{array}$ & $\begin{array}{l}27(51.0) \\
26(49.0)\end{array}$ \\
\hline
\end{tabular}


9 with stage II, 16 with stage III, and 26 patients with stage IV. In the ESCC patients, the cachexia syndrome was defined as involuntary weight loss exceeding $5 \%$ of the patient's previous baseline body weight during a 3-month period.

Blood samples were collected after overnight fasting from the 53 ESCC patients prior to any treatment. From the 27 patients who underwent esophagectomy (17 men, 10 women, mean age 59.7 years), samples of the tumor and matched non-tumor tissue were collected for the analysis of mRNA and protein expression.

Serum from 27 apparently healthy blood donors (16 men, 11 women, mean age $55.9 \pm 3.6$ years) from the Regional Blood Donation and Treatment Center (Wrocław, Poland) was used as a reference in the analysis of circulating adipokines. The control group was age- and gender-matched to the study group $(\mathrm{p}>0.05)$.

\section{Ethical considerations}

The study was planned according to the ethical standards detailed in the Declaration of Helsinki, as revised in 1983. The study protocol was approved by the Medical Ethics Committee of Wroclaw Medical University (Poland). Informed consent was obtained from all the subjects.

\section{Collection and preparation of samples}

Fresh specimens of tumor and normal mucosa, the latter taken approx. $10 \mathrm{~cm}$ from the tumor, were collected after the resection and divided into 2 sets. The $1^{\text {st }}$, subsequently used for transcriptional analysis, was soaked in RNAlater ${ }^{\circledR}$ stabilizing solution (Ambion Inc., Austin, USA) and stored at $-80^{\circ} \mathrm{C}$; the $2^{\text {nd }}$, subsequently used for protein analysis, was rinsed with $0.9 \% \mathrm{NaCl}$ and stored at $-45^{\circ} \mathrm{C}$.

Tissue samples for RNA extraction (30-40 mg) were homogenized in TRIzol Reagent (Invitrogen Life Technologies, Carlsbad, USA) using a Fastprep 24 Homogenizer (MP Biomedicals, Santa Ana, USA) and total RNA was extracted using the phenol-chloroform method. The isolated RNA was purified using an RNeasy Mini Kit (Qiagen Inc., Germantown, USA) with DNase treatment in accordance with the manufacturer's instructions. The purified RNA was quantified with a NanoDrop 2000 spectrophotometer (Thermo Fisher Scientific Inc., Waltham, USA). Its purity was assessed by calculating 260/280 and 260/230 ratios. RNA integrity was evaluated using the Experion platform incorporating LabChip microfluidic technology and Experion RNA StdSens analysis kits (Bio-Rad Laboratories, Hercules, USA).

To determine the protein concentration, the tissue samples were homogenized in $10 \mathrm{mM}$ Tris- $\mathrm{HCl}$ with $150 \mathrm{mM}$ $\mathrm{KCl}$ and $1 \mathrm{mM}$ ethylenediaminetetraacetic acid (EDTA) pH 7.4 buffer (proportion 1:2 w/v) using a FastPrep-24 homogenizer (MP Biomedicals) for $2 \mathrm{~min}$ at $4.0 \mathrm{~m} / \mathrm{s}$. The homogenates were centrifuged at $14,500 \times$ g for $10 \mathrm{~min}$ at $6^{\circ} \mathrm{C}$ and supernatants were collected and stored at $-45^{\circ} \mathrm{C}$.
The blood samples were clotted (30 min, room temperature) and centrifuged at $1500 \times \mathrm{g}$ for $10 \mathrm{~min}$ at room temperature. The serum obtained was stored at $-45^{\circ} \mathrm{C}$.

\section{Analytical methods}

The concentrations of adipokines in the tissue homogenates and serum were determined in duplicate using commercially available enzyme-linked immunosorbent assay (ELISA) kits. Apelin and apelin receptor concentrations were determined using human ELISA kits (MyBioSource Inc., San Diego, USA). The sensitivity of the apelin assay was $2.63 \mathrm{pg} / \mathrm{mL}$, while intra- and inter-assay coefficients of variation (CV) were $<10 \%$ and $<12 \%$, respectively. The sensitivity of the apelin receptor assay was $1.0 \mathrm{ng} / \mathrm{mL}$, and both the intra- and inter-assay CVs were less than 15\%. Resistin and adiponectin concentrations in the serum and tissue homogenates were measured using ELISA kits provided by R\&D Systems (Abingdon, UK). The sensitivity of the resistin assay was $0.026 \mathrm{ng} / \mathrm{mL}$, and the intra- and inter-assay CVs were $3.8-5.3 \%$ and $7.8-9.2 \%$, respectively. The sensitivity of the adiponectin assay was $0.246 \mathrm{ng} / \mathrm{mL}$, while the intra- and interassay CVs were $2.5-4.7 \%$ and $5.8-6.9 \%$, respectively.

In the case of the tissue samples, adipokine levels were adjusted to total protein level, measured using the Bradford method with the Bio-Rad Protein Assay (Bio-Rad Laboratories). Bovine serum albumin was used for standard curve preparation. Concentrations were expressed as nanograms or micrograms of adipokine per grams of total protein content.

Adipokine mRNA expression levels were determined using reverse transcription quantitative polymerase chain reaction (RT-qPCR) analysis. The amount of $0.5 \mu \mathrm{g}$ of RNA was transcribed using a Maxima First Strand cDNA Synthesis Kit (Thermo Fisher Scientific Inc., Waltham, USA) according to the manufacturer's instructions. Negative transcription controls were performed and tested for all samples. All the incubation steps were carried out in a C1000 Thermal Cycler (Bio-Rad Laboratories).

The qPCR reaction mixture consisted of $2 \mu \mathrm{L}$ of cDNA (diluted 1:5), $10 \mu \mathrm{L}$ of SsoFast EvaGreen Supermix (Bio-Rad Laboratories), $1 \mu \mathrm{L}$ of each $10 \mathrm{nM}$ forward and reverse targetspecific primer, and $6 \mu \mathrm{L}$ of water. A list of the primers used in this study (provided by GeneSys Sp. z o.o., Wrocław, Poland) is presented in Table 2 . The reactions were conducted in triplicate using the CFX96 RT-PCR system (Bio-Rad Laboratories) with the following cycling conditions: $95^{\circ} \mathrm{C}$ for $30 \mathrm{~s}, 95^{\circ} \mathrm{C}$ for $5 \mathrm{~s}$ and $61^{\circ} \mathrm{C}$ for $5 \mathrm{~s}, 40$ cycles. The specificity of the product was confirmed with melting curve analysis $\left(60-90^{\circ} \mathrm{C}\right.$ with a fluorescence reading every $0.5^{\circ} \mathrm{C}$ ) and with electrophoresis in a high-resolution agarose (SeaKem LE agarose; Lonza Ltd., Basel, Switzerland) in Tris/Borate/EDTA (TBE) buffer with SYBR Green (Lonza Ltd.) detection. For each sample, the expression of toll-like receptors (TLRs) was examined and normalized to the GAPDH reference gene, and relative induction was calculated using the $2^{(-\Delta \Delta \mathrm{Ct})}$ method. ${ }^{16}$ 
Table 2. qPCR primer sequences used to detect apelin, apelin receptor, resistin, and adiponectin

\begin{tabular}{|c|c|}
\hline Gene & Primer sequence \\
\hline Apelin & $\begin{array}{l}\text { forward: CAG GGA GGT CGG AGG AAA T } \\
\text { reverse: ACC AAT CTA TGG AGG AGA CAT AAC C }\end{array}$ \\
\hline Apelin receptor & $\begin{array}{l}\text { forward: ACT TCC GCA AGG AAC GCA TCG A } \\
\text { reverse: ACA GCG TCT TCA CCA GGT GGT A }\end{array}$ \\
\hline Resistin & $\begin{array}{l}\text { forward: TGG AGT GCC AGA GCG TCA CCT } \\
\text { reverse: ACT GGC AGT GAC ATG TGG TCT C }\end{array}$ \\
\hline Adiponectin & $\begin{array}{l}\text { forward: CAG GCC GTG ATG GCA GAG ATG } \\
\text { reverse: GGT TTC ACC GAT GTC TCC CTT AG }\end{array}$ \\
\hline
\end{tabular}

\section{Statistical analysis}

All the data was analyzed using STATISTICA v. 13.0 software (StatSoft Inc., Tulsa, USA) and MedCalc v. 16.8.4 software (MedCalc Software, Ostend, Belgium). The distribution of the data was tested with the Shapiro-Wilk normality test. Descriptive data were presented as medians and min-max values (for quantitative variables) and as numbers of observations and percentages (for qualitative variables). Independent samples were analyzed using the Mann-Whitney U test, the Kruskal-Wallis analysis of variance and the post-hoc Dunn test. Paired samples were tested using the Wilcoxon test. Frequency analyses were conducted with the Fisher's exact test. Spearman's rank correlation coefficients $(\rho)$ were calculated to evaluate associations between pairs of variables. P-values $<0.05$ were considered statistically significant.

\section{Results}

\section{Protein concentrations of apelin, apelin receptor, resistin, and adiponectin in the primary tumors of cancer patients}

The protein expression of apelin, apelin receptor, resistin, and adiponectin in tumor tissue and adjacent normal mucosa are presented in Table 3. Apelin, apelin receptor and resistin levels were significantly higher in tumor tissue than in the corresponding control tissue $(\mathrm{p}<0.05)$, whereas adiponectin concentration was non-significantly lower in the primary tumors than in control tissue $(\mathrm{p}=0.058)$.

Tumor concentrations of adipokines were evaluated in relation to demographical, clinical and pathological parameters. Apelin levels significantly increased in the patients with lymph node metastases (median for pN0: 862.3 (701.9-1084.7) ng/g protein vs median for $\mathrm{pN} 1: 1165.7$ (794.2-1535.7) ng/g protein, $\mathrm{p}=0.005$ ) (Fig. 1). Correlations between other study parameters were not found.

\section{Pairwise comparison of apelin, apelin receptor, resistin, and adiponectin mRNA expression between the primary tumors and normal mucosa of cancer patients}

An analysis of apelin, apelin receptor and resistin mRNA expression showed upregulated levels of these adipokines in tumor tissue as compared to normal tissue: 4.0-fold for apelin ( $\mathrm{p}<0.0001), 3.4$-fold for the apelin receptor ( $\mathrm{p}=0.0008)$ and 4.4-fold for resistin $(\mathrm{p}<0.0001)$. Adiponectin mRNA expression was 2.2-fold lower in the tumors than in the control tissue $(\mathrm{p}=0.0255)$ (Table 4).

No correlations were found between the mRNA and protein expression of adipokines in tumor tissues.

\section{Circulating levels of apelin, apelin receptor, resistin, and adiponectin in cancer patients}

Serum apelin, apelin receptor, resistin, and adiponectin concentrations were measured in the group of 53 stage I-IV ESCC patients and in the 27 healthy controls, and the results are presented in Table 5. The median concentrations of serum apelin, apelin receptor and resistin were significantly higher in the cancer patients than in the controls ( $p<0.05$ for all). There was no significant difference between the ESCC group and the control group in terms of serum adiponectin levels.

Relationships between demographic, clinical or pathological parameters and concentrations of serum adipokines in the ESCC patients are shown in Table 6. There were

Table 4. Apelin, apelin receptor, resistin, and adiponectin mRNA expression in the tumor tissue of ESCC patients. Gene expression was normalized to control tissue and analyzed using the Wilcoxon test

\begin{tabular}{|l|c|c|}
\multicolumn{1}{|c|}{ Gene expression } & Median (min-max) & p-value \\
\hline Apelin & $4.11(0.13-36.75)$ & $<0.0001^{*}$ \\
\hline Apelin receptor & $2.16(0.20-98.38)$ & $0.0008^{*}$ \\
\hline Resistin & $9.85(0.47-86.10)$ & $<0.0001^{*}$ \\
\hline Adiponectin & $0.23(0.00-6.06)$ & $0.0255^{*}$ \\
\hline
\end{tabular}

*statistically significant at $p<0.05$

Table 3. Pairwise comparison of tumor and normal tissue apelin, apelin receptor, resistin, and adiponectin levels in surgically treated ESCC patients. Data was analyzed using Wilcoxon test

\begin{tabular}{|l|c|c|c|}
\hline \multicolumn{1}{|c|}{ Variable } & Tumor tissue, median (min-max) & Control tissue, median (min-max) & p-value \\
\hline Apelin [ng/g protein] & $938.4(701.9-1535.7)$ & $851.9(427.9-1398.6)$ & $0.001^{*}$ \\
\hline Apelin receptor $[\mu \mathrm{g} / \mathrm{g}$ protein] & $240.0(84.2-833.9)$ & $47.1(4.5-446.7)$ & $<0.0001^{*}$ \\
\hline Resistin $[\mu \mathrm{g} / \mathrm{g}$ protein] & $7.2(1.0-37.2)$ & $1.0(0.2-2.9)$ & $<0.0001^{*}$ \\
\hline Adiponectin $[\mu \mathrm{g} / \mathrm{g}$ protein] & $64.6(39.4-122.6)$ & $78.3(37.5-163.4)$ & 0.058 \\
\hline
\end{tabular}


statistically higher levels of serum apelin in the patients with cachexia $(\mathrm{p}=0.006)$. Levels of serum apelin tended to be significantly higher in patients at higher TNM stages $(p=0.052)$. Concentrations of serum apelin receptor significantly decreased in ESCC patients with stage IV cancer ( $p=0.0065)$ and the presence of lymph node or distant metastases ( $\mathrm{p}=0.005$ and $\mathrm{p}=0.004$, respectively). No differences were observed between study parameters and concentrations of serum resistin and adiponectin in the cancer patients.

We observed a positive correlation between resistin protein expression in the tumors and in serum $(\rho=0.48$, $\mathrm{p}=0.011)$ (Fig. 2).

\section{Discussion}

It has been demonstrated that apelin can influence cancer development and progression, and the apelin/apelin receptor system may play a crucial role in tumor angiogenesis. ${ }^{12}$ However, there have been no studies of the clinical and pathological relevance of apelin and its receptor in ESCC.

To the best of our knowledge, this is the first study that has demonstrated increases in apelin and apelin receptor mRNA expression and protein levels in the tumors of ESCC patients. A similar result was reported in nonsmall cell lung cancer (NSCLC) tumors, where overexpression of apelin mRNA was shown by immunohistochemistry. A positive correlation between apelin mRNA and protein expression in human NSCLC specimens was reported. ${ }^{13}$ Picault et al. have shown high levels of apelin and the apelin receptor in colon adenoma and adenocarcinoma. ${ }^{17}$ They suggest that the apelin/apelin receptor system may participate in the growth of colon cancer through stimulation of anti-apoptotic pathways. Based on suggestions from previous research, we hypothesize that a high frequency of apelin and apelin receptor expression on the gene and protein levels might be significantly associated with ESCC development. Our results also showed significantly higher concentrations of serum apelin and apelin receptor in the cancer patients than in healthy controls, which additionally suggests the important role of these adipokines in the process of ESCC carcinogenesis.

Our investigation of associations between clinicopathological parameters and protein expression of apelin and apelin receptor levels in ESCC tumors revealed a significant relationship between high apelin levels and lymph node metastases. We did not find a similar correlation in the case of apelin receptor concentrations. Clinical and experimental studies by Berta et al. found that apelin might be a proangiogenic factor in NSCLC, and the apelin/apelin receptor system might induce lymphangiogenesis. ${ }^{13,18}$ A study by Heo et al. confirmed that apelin is an independent prognostic factor for lymph node metastasis in oral squamous cell carcinoma patients. ${ }^{19}$

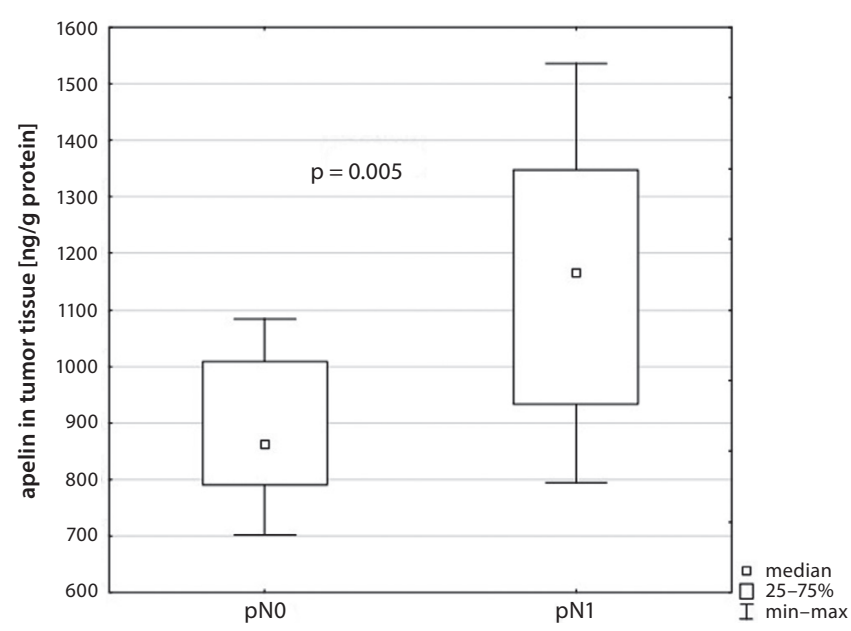

Fig. 1. Protein levels of apelin in tumor tissues of ESCC patients without ( $\mathrm{pN} 0$ ) and with (pN1) lymph node metastases

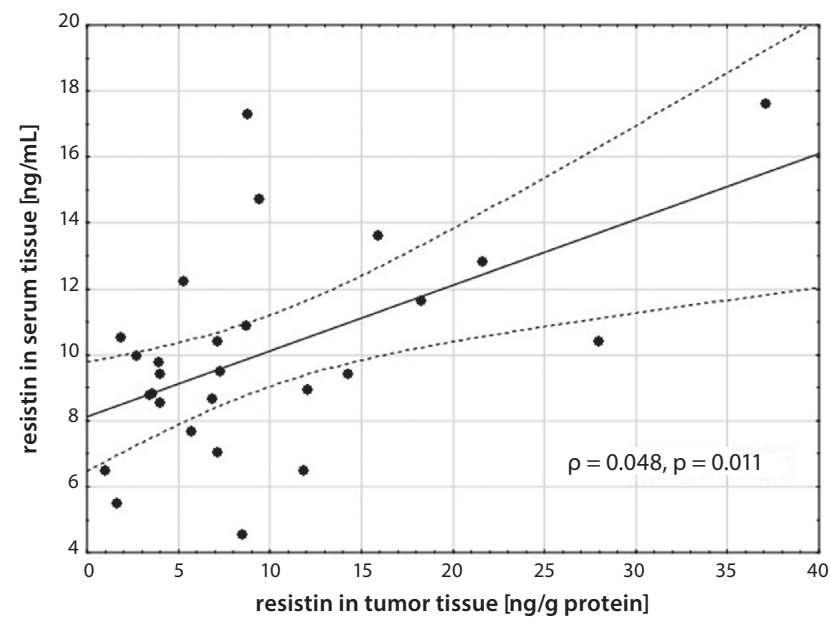

Fig. 2. The positive correlation between resistin levels in tumors and its concentration in the serum of ESCC patients. The data was demonstrated using Spearman's rank correlation coefficient $(\rho)$

In vitro studies by Sorli et al. showed that apelin is a mitogenic factor for endothelial cells, and the overexpression of apelin receptor mRNA during the formation of new blood vessels has an influence on vascular network intensity in tumors. ${ }^{20}$ They also reported that overexpression of apelin and apelin receptor stimulate tumor growth, and that this increase is related to earlier initiation of tumor development. They suggest that the observed effect is independent of the influence of tumor cells, and apelin could act on tumor neoangiogenesis via a paracrine action on the endothelial cells of the host vessels. In addition, Kalin et al. have shown that apelin and the apelin receptor are upregulated in microvascular proliferations during tumor angiogenesis in malignant gliomas. ${ }^{21}$

These reports led us to formulate the suggestion that the highest levels of apelin in the tumors of patients with lymph node metastases might confirm the paracrine effect of the apelin/apelin receptor system on vascular and lymphatic endothelial cells and the activation of neoangiogenic and lymphangiogenic processes in ESCC. 
In our previous research, no significant differences between clinicopathological parameters and apelin concentrations in the serum of gastroesophageal cancer patients were found. In the present study, we observed a significant increase of serum apelin in the ESCC patients with cachexia syndrome and a tendency toward an increase in serum apelin levels in patients with advanced stages of the disease. This suggests that apelin may contribute to cachexia development through its participation in the systemic inflammatory response.

Although concentrations of serum apelin receptor were significantly higher in the ESCC patients than in the healthy controls, we found decreases in circulating apelin receptor in relation to the cancer patients' tumor stage progression, lymph node and distant metastases. This may suggest that the apelin receptor is intensely produced in the early stage of cancer development and may possibly take part in the carcinogenesis processes in ESCC. Further studies on larger groups of patients with stage I and II disease are necessary to evaluate the role of serum apelin receptor in ESCC.

Our study is the first to demonstrate that resistin mRNA and protein expression were significantly higher in tumor tissue than in normal mucosa in ESCC patients. These results are consistent with our previous study, where we found significant increases in resistin levels in the tumor tissue of gastroesophageal cancer patients. ${ }^{10}$ Although no significant associations between the clinicopathological parameters and resistin protein expression in ESCC tumor tissue were found, other studies have reported that resistin plays an important role in tumor growth, neoangiogenesis and metastasis, and also in the differentiation and migration of endothelial cells in cancers. ${ }^{4,7,21-25}$

Table 5. Concentration of serum apelin, apelin receptor, resistin, and adiponectin in esophageal squamous cell carcinoma (ESCC) patients and healthy controls. Data was analyzed using the Mann-Whitney $U$ test

\begin{tabular}{|l|c|c|c|}
\multicolumn{1}{|c|}{ Variable } & $\begin{array}{c}\text { ESCC patients }(n=53), \\
\text { median (min-max) }\end{array}$ & $\begin{array}{c}\text { Control group }(n=27), \\
\text { median }(\text { min-max) }\end{array}$ & p-value \\
\hline Apelin $[\mathrm{pg} / \mathrm{mL}]$ & $746.7(314.4-1160.7)$ & $570.0(340.0-960.0)$ & $0.036^{*}$ \\
\hline Apelin receptor $[\mathrm{ng} / \mathrm{mL}]$ & $15.8(3.1-55.0)$ & $7.2(4.8-9.4)$ & $<0.0001^{*}$ \\
\hline Resistin $[\mathrm{ng} / \mathrm{mL}]$ & $9.4(4.5-17.6)$ & $7.2(1.9-14.3)$ & $0.0007^{*}$ \\
\hline Adiponectin $[\mu \mathrm{g} / \mathrm{mL}]$ & $9.6(2.1-18.7)$ & $9.9(4.1-17.2)$ & 0.831 \\
\hline
\end{tabular}

* statistically significant at $\mathrm{p}<0.05$

Table 6. Relationships between demographic, clinical and pathological parameters and concentrations of serum adipokines in esophageal squamous cell carcinoma (ESCC) patients $(n=53)$. Data was analyzed using the Mann-Whitney $U$ test (when 2 independent samples were compared), the Kruskal-Wallis test (when 3 independent samples were compared) and post-hoc Dunn's test (for intragroup comparison)

\begin{tabular}{|c|c|c|c|c|c|c|c|c|}
\hline \multirow{2}{*}{ Parameter } & \multicolumn{2}{|c|}{ Apelin [pg/mL] } & \multicolumn{2}{|c|}{ Apelin receptor [ng/mL] } & \multicolumn{2}{|c|}{ Resistin [ng/mL] } & \multicolumn{2}{|c|}{ Adiponectin $(\mu \mathrm{g} / \mathrm{mL})$} \\
\hline & median (min-max) & $p$-value & median (min-max) & $p$-value & median (min-max) & $p$-value & median (min-max) & $p$-value \\
\hline $\begin{array}{l}\text { Age: } \\
\qquad 60(n=27) \\
>60(n=26)\end{array}$ & $\begin{array}{l}698.9(320.8-1117.8) \\
809.3(314.4-1160.7)\end{array}$ & 0.319 & $\begin{array}{l}14.8(4.0-54.4) \\
17.2(3.1-55.0)\end{array}$ & 0.810 & $\begin{array}{l}9.5(5.7-17.3) \\
9.0(4.5-17.6)\end{array}$ & 0.999 & $\begin{array}{r}8.8(2.1-16.8) \\
10.5(5.5-18.8)\end{array}$ & 0.083 \\
\hline $\begin{array}{l}\text { Gender: } \\
\text { male }(n=36) \\
\text { female }(n=17)\end{array}$ & $\begin{array}{l}779.9(314.4-1160.7) \\
648.9(388.3-1001.8)\end{array}$ & 0.457 & $\begin{array}{l}15.4(4.0-54.4) \\
16.6(3.1-55.0)\end{array}$ & 0.668 & $\begin{array}{l}9.6(5.7-17.6) \\
8.9(4.5-14.3)\end{array}$ & 0.336 & $\begin{array}{l}9.5(2.1-16.8) \\
9.9(5.5-18.8)\end{array}$ & 0.112 \\
\hline $\begin{array}{l}\text { Cachexia: } \\
\text { yes }(n=20) \\
\text { no }(n=33)\end{array}$ & $\begin{array}{l}907.6(565.4-1160.7) \\
671.7(314.4-1107.4)\end{array}$ & $0.006^{*}$ & $\begin{array}{l}14.4(8.3-30.4) \\
16.6(3.1-55.0)\end{array}$ & 0.657 & $\begin{array}{l}9.5(5.7-14.7) \\
9.3(4.5-17.6)\end{array}$ & 0.539 & $\begin{array}{r}10.5(5.5-16.8) \\
9.5(2.1-18.8)\end{array}$ & 0.882 \\
\hline $\begin{array}{l}\text { PTNM: } \\
\begin{array}{l}\text { I + II }(n=11) \\
\text { III }(n=16) \\
\text { IV }(n=26)\end{array}\end{array}$ & $\begin{array}{l}577.9(388.3-1083.4) \\
828.9(320.8-1160.7) \\
722.8(314.4-949.8)\end{array}$ & 0.052 & $\begin{array}{l}24.9(3.1-55.0) \mathrm{A} \\
16.8(4.0-36.2) \\
13.1(5.2-32.8) \mathrm{A}\end{array}$ & $0.007^{*}$ & $\begin{array}{l}9.9(4.5-17.3) \\
9.4(6.5-17.6) \\
9.2(5.7-15.6)\end{array}$ & 0.853 & $\begin{array}{r}9.5(6.8-14.2) \\
10.2(3.1-16.8) \\
9.5(2.1-18.8)\end{array}$ & 0.865 \\
\hline $\begin{array}{l}\text { pT: } \\
1+2(n=9) \\
3(n=15) \\
4(n=29)\end{array}$ & $\begin{array}{l}577.9(395.7-1027.8) \\
790.5(320.8-1160.7) \\
746.7(314.4-1015.6)\end{array}$ & 0.404 & $\begin{array}{l}24.9(3.1-55.0) \\
15.8(4.0-30.4) \\
13.8(5.2-36.2)\end{array}$ & 0.074 & $\begin{array}{c}10.0(4.5-17.3) \\
9.4(5.5-14.7) \\
9.3(5.7-17.6)\end{array}$ & 0.869 & $\begin{array}{r}9.5(7.3-14.2) \\
10.0(4.5-16.8) \\
9.3(2.1-18.8)\end{array}$ & 0.632 \\
\hline $\begin{array}{l}\text { pN: } \\
0(n=14) \\
1(n=39)\end{array}$ & $\begin{array}{l}660.4(388.3-1083.4) \\
805.5(314.4-1160.7)\end{array}$ & 0.237 & $\begin{array}{l}25.3(3.1-55.0) \\
14.4(4.0-36.2)\end{array}$ & $0.005^{*}$ & $\begin{array}{l}9.9(4.5-17.3) \\
9.3(5.7-17.6)\end{array}$ & 0.864 & $\begin{array}{l}9.5(5.5-16.8) \\
9.9(2.1-18.8)\end{array}$ & 0.538 \\
\hline $\begin{array}{l}\text { pM: } \\
0(n=27) \\
1(n=26)\end{array}$ & $\begin{array}{l}756.6(320.8-1160.7) \\
722.8(314.4-949.8)\end{array}$ & 0.251 & $\begin{array}{l}21.3(3.1-55.0) \\
13.1(5.2-32.8)\end{array}$ & $0.004^{*}$ & $\begin{array}{l}9.5(4.5-17.6) \\
9.2(5.7-15.6)\end{array}$ & 0.587 & $\begin{array}{l}9.9(3.1-16.8) \\
9.5(2.1-18.8)\end{array}$ & 0.978 \\
\hline
\end{tabular}

* statistically significant at $p<0.05 ; A$ - post-hoc test for I + II vs IV, $p=0.0065$. 
The present study demonstrated significantly higher concentrations of serum resistin in the ESCC patients than in the; however, no relationships between serum levels of resistin and clinicopathological parameters were found. Increases in serum resistin concentration were observed in patients with colon, gastric, esophageal, and endometrial cancer, ${ }^{6,8,14,26}$ or in the saliva of patients with oral cavity squamous cell carcinoma. ${ }^{15}$

Our study demonstrated significantly lower adiponectin mRNA expression in the tumors than in the control mucosa of the ESCC patients. We observed no significant differences between the clinicopathological parameters and protein levels in tumors or serum concentrations of adiponectin. These results are in opposition to some earlier studies. For example, Guo et al. used immunohistochemistry and western blot analyses to establish that adiponectin expression was significantly lower in tumor tissue than in adjacent non-malignant epithelial tissue in tongue squamous cell carcinoma. ${ }^{27}$ Nakajima et al. and Yildrim et al. also found significantly lower concentrations of serum adiponectin in esophageal cancer patients than in healthy controls. ${ }^{8,11}$

Circulating levels of adiponectin decreased with tumor stage progression. Similar results have been reported in other malignancies, such as gastric and gastrointestinal cancers. ${ }^{2,6,14,28,29}$ and in tongue squamous cell carcinoma, ${ }^{27}$ head and neck squamous cell carcinoma ${ }^{30}$ or non-small cell lung cancer. ${ }^{3,31}$ Our previous study on gastroesophageal cancer also showed significantly lower levels of serum adiponectin in patients with metastases to the lymph nodes and/or distant regions of body and in patients with cachexia syndrome. ${ }^{10}$

However, it has been suggested in earlier studies that decreases in adiponectin levels cannot be associated with cachexia processes but rather with mechanisms of cancer progression. ${ }^{7,28}$ This implies that decreases in adiponectin levels may possibly play a role in cancer cell invasion and metastasis. On the other hand, increases in serum adiponectin levels have been found in cachectic patients with gastrointestinal cancer ${ }^{29}$ and in patients with head and neck squamous cell carcinoma. ${ }^{32}$ Reductions in overall survival for men with ESCC who had increased concentrations of serum adiponectin have also been demonstrated. ${ }^{33}$ Therefore, further research is necessary to clarify the role of adiponectin in ESCC.

\section{References}

1. Kitayama J, Tabuchi M, Tsurita G, Ishikawa M, Otani K, Nagawa H. Adiposity and gastrointestinal malignancy. Digestion. 2009;79(Suppl 1): 26-32. doi: 10.1159/000167863

2. Ntikoudi E, Kiagia M, Boura P, Syrigos KN. Hormones of adipose tissue and their biologic role in lung cancer. Cancer Treat Rev. 2014; 40(1):22-30. doi: 10.1016/j.ctrv.2013.06.005

3. Karapanagiotou EM, Tsochatzis EA, Dilana KD, Tourkantonis I, Gratsias I, Syrigos KN. The significance of leptin, adiponectin, and resistin serum levels in non-small cell lung cancer (NSCLC). Lung Cancer. 2008;61(3):391-397. doi: 10.1016/j.lungcan.2008.01.018

4. Nieman KM, Romero IL, Van Houten B, Lengyel E. Adipose tissue and adipocytes support tumorigenesis and metastasis. Biochim Biophys Acta. 2013;1831(10):1533-1541. doi: 10.1016/j.bbalip.2013.02.010
5. Friedenreich CM, Biel RK, Lau DC, et al. Case-control study of the metabolic syndrome and metabolic risk factors for endometrial cancer. Cancer Epidemiol Biomarkers Prev. 2011;20(11):2384-2395. doi: 10.1158/1055-9965.EPI-11-0715

6. Gonullu G, Kahraman H, Bedir A, Bektas A, Yücel I. Association between adiponectin, resistin, insulin resistance, and colorectal tumors. Int J Colorectal Dis. 2010;25(2):205-212. doi: 10.1007/s00384009-0828-6

7. Tiaka EK, Manolakis AC, Kapsoritakis AN, Potamianos SP. The implication of adiponectin and resistin in gastrointestinal diseases. Cytokine Growth Factor Rev. 2011;22(2):109-119. doi: 10.1016/j.cytogfr.2011.04.002

8. Nakajima TE, Yamada $Y$, Hamano $T$, et al. Adipocytokines and squamous cell carcinoma of the esophagus. J Cancer Res Clin Oncol. 2010;136(2):261-266. doi: 10.1007/s00432-009-0657-6

9. Nakayama A, Aoki S, Uchihashi K, et al. Interaction between esophageal squamous cell carcinoma and adipose tissue in vitro. Am J Pathol. 2016;186(5):1180-1194. doi: 10.1016/j.ajpath.2016.01.003

10. Diakowska D, Markocka-Mączka K, Szelachowski P, Grabowski K. Serum levels of resistin, adiponectin, and apelin in gastroesophageal cancer patients. Dis Markers. 2014;2014:619649. doi: 10.1155/2014/619649

11. Yildirim A, Bilici M, Cayir K, Yanmaz V, Yildirim S, Tekin SB. Serum adiponectin levels in patients with esophageal cancer. Jpn J Clin Oncol. 2009;39(2):92-96. doi: 10.1093/jjco/hyn143

12. Yang Y, Lv SY, Ye W, Zhang L. Apelin/APJ system and cancer. Clin Chim Acta. 2016;457:112-116. doi: 10.1016/j.cca.2016.04.001

13. Berta J, Hoda MA, Laszlo V, et al. Apelin promotes lymphangiogenesis and lymph node metastasis. Oncotarget. 2014;5(12):4426-4423.

14. Nakajima TE, Yamada Y, Hamano T, et al. Adipocytokine levels in gastric cancer patients: resistin and visfatin as biomarkers of gastric cancer. J Gastroenterol. 2009;44(7):685-690. doi: 10.1007/s00535009-0063-5

15. Wu CC, Chu HW, Hsu CW, Chang KP, Liu HP. Saliva proteome profiling reveals potential salivary biomarkers for detection of oral cavity squamous cell carcinoma. Proteomics. 2015;15(19):3394-3404. doi: 10.1002/pmic.201500157

16. Livak KJ, Schmittgen TD. Analysis of relative gene expression data using real-time quantitative PCR and the 2(-Delta Delta $C(T)$ ) Method. Methods. 2001;25(4):402-408.

17. Picault FX, Chaves-Almagro C, Projetti F, Prats H, Masri B, Audigier $Y$. Tumour co-expression of apelin and its receptor is the basis of an autocrine loop involved in the growth of colon adenocarcinomas. Eur J Cancer. 2014;50(3):663-674. doi: 10.1016/j.ejca.2013.11.017

18. Berta J, Kenessey I, Dobos J, et al. Apelin expression in human nonsmall cell lung cancer: Role in angiogenesis and prognosis. $J$ Thorac Oncol. 2010;5(8):1120-1129. doi: 10.1097/JTO.0b013e3181e2c1ff

19. Heo K, Kim YH, Sung HJ, et al. Hypoxia-induced up-regulation of apelin is associated with a poor prognosis in oral squamous cell carcinoma patients. Oral Oncol. 2012;48(6):500-506. doi: 10.1016/j.oraloncology.2011.12.015

20. Sorli SC, Le Gonidec S, Knibiehler B, Audigier Y. Apelin is a potent activator of tumour neoangiogenesis. Oncogene. 2007;26(55):7692-7699.

21. Kälin RE, Kretz MP, Meyer AM, Kispert A, Heppner FL, Brändli AW. Paracrine and autocrine mechanisms of apelin signaling govern embryonic and tumor angiogenesis. Dev Biol. 2007;305(2):599-614.

22. Filková M, Haluzík M, Gay S, Senolt L. The role of resistin as a regulator of inflammation: Implications for various human pathologies. Clin Immunol. 2009;133(2):157-170. doi: 10.1016/j.clim.2009.07.013

23. Steppan CM, Brown EJ, Wright CM, et al. A family of tissue-specific resistin-like molecules. Proc Natl Acad Sci U S A. 2001;98(2):502-506.

24. Sălăgeanu $A$, Tucureanu $C$, Lerescu $L$, et al. Serum levels of adipokines resistin and leptin in patients with colon cancer. $J$ Med Life. 2010;3(4):416-420.

25. Tsai $\mathrm{CH}$, Tsai $\mathrm{HC}$, Huang $\mathrm{HN}$, et al. Resistin promotes tumor metastasis by down-regulation of miR-519d through the AMPK/p38 signaling pathway in human chondrosarcoma cells. Oncotarget. 2015;6(1): 258-270. doi: 10.18632/oncotarget.2724

26. Hlavna M, Kohut L, Lipkova J, et al. Relationship of resistin levels with endometrial cancer risk. Neoplasma. 2011;58(2):124-128.

27. Guo XH, Wang JY, Gao Y, et al. Decreased adiponectin level is associated with aggressive phenotype of tongue squamous cell carcinoma. Cancer Sci. 2013;104(2):206-213. doi: 10.1111/cas.12077 
28. Kerem M, Ferahkose Z, Yilmaz UT, et al. Adipokines and ghrelin in gastric cancer cachexia. World J Gastroenterol. 2008;14(23):3633-3641.

29. Batista ML Jr, Olivan M, Alcantara PS, et al. Adipose tissue-derived factors as potential biomarkers in cachectic cancer patients. Cytokine. 2013;61(2):532-539. doi: 10.1016/j.cyto.2012.10.023

30. de Carvalho TM, Miguel Marin D, da Silva CA, et al. Evaluation of patients with head and neck cancer performing standard treatment in relation to body composition, resting metabolic rate, and inflammatory cytokines. Head Neck. 2015;37(1):97-102. doi: 10. 1002/hed.23568

31. Gulen ST, Karadag F, Karul AB, et al. Adipokines and systemic inflammation in weight-losing lung cancer patients. Lung. 2012;190(3): 327-332. doi: 10.1007/s00408-011-9364-6
32. Young MR, Levingston C, Johnson SD. Cytokine and adipokine levels in patients with premalignant oral lesions or in patients with oralcancer who did or did not receive 1a,25-Dihydroxy vitamin D3 treatment upon cancer diagnosis. Cancers (Basel). 2015;7(3):1109-1124. doi: 10.3390/cancers7030827

33. Zemanová $M$, Staňková $B$, Ušiakova Z, et al. Serum adiponectin relates to shortened overall survival in men with squamous cell esophageal cancer treated with preoperative concurrent chemoradiotherapy: A pilot study. Med Sci Monit. 2014;20:2351-2357. doi: 10.12659/ MSM.891088 